\title{
Spirituality During Aging
}

Ernest G. Hall, S.T.M., D. Min. University of Michigan Medical Center, Ann Arbor, Michigan

\begin{abstract}
This paper suggests that an understanding of spirituality during aging provides an important supplement for the developmental model in looking at the religious lives of older persons. Jung's perspective on the psychodynamics of human spirit is compared with Allport's description of mature religious sentiment in order to present a basis for looking at three case studies of nursing home residents. Each case addresses a major challenge faced in the later years of life: 1) self-worth, 2) the meaning of one's life, 3 ) losses in aging. An understanding of the developmental issues faced in late life supplemented with an appreciation for a person's spirituality may help us better minister to older persons.
\end{abstract}

When we begin an examination of the religious character of older persons, we at once confront a problem which is not limited to discussions of religion among the aging. This is the problem of the breadth of the category of human experience which we call religious. We can examine religion as a sociocultural phenomenon, as a philosophical orientation, as an ethical system, or as a psychological manifestation. My tendency is to approach the topic from a psychological perspective. Thus, I shall be presenting my discussion from the perspective of a psychology of religion.

One way to tackle a topic as broad as religion is to divide it into parts. This approach to religious experience has been taken by many contemporary scholars through the application of developmental theory as set forth by Erikson and his colleagues (Hiltner, Aging, 1975). As we know, Erikson suggested that the nuclear crisis confronted during old age is the conflict centering around integrity versus despair. The resulting virtue, he suggested, is wisdom. Browning has certainly presented a thoughtful treatment of religion in the stages of development in his book, Generative Man (1973).

Another way to look at religion during aging is a psychodynamic approach. This approach has its roots in psychoanalysis and depth psychology, beginning with Freud and Jung.

The psychodynamic approach focuses in part upon the dynamics of the spirit in the psyche. I want to suggest in this paper that an understanding of the function of the spirit during aging is an important sup- 
plement to a developmental perspective toward religion in later years. To do this I shall first sketch a working definition of spirit, noting its religious expression, and then present three case studies which exemplify this understanding.

The American Heritage Dictionary (1973) defines spirit as "the vital principle or animating force whithin living beings." Jung sharpened this description for us by observing that the spirit acts as a guiding principle within psychic life which, in part, governs the expressions of the various components of the psyche (Collected Works, vol, 8, p.206). It is the creative, constructive, regulatory dynamic within the psyche which leads psychic processes forward toward fullness of expression and balanced functioning. It is the dynamic of constructive relationships among the psychic processes (Hall, "Spirit," 1981). Jacobi has described the dynamic of spirit as leading to meaningful insights and valuational judgements, as thus being a formative principle in psychic life (Jacobi, Jung, 1973). It is clear from these descriptions that the function of human spirit is not confined to the conflicts faced during only one stage of life.

In early stages of life, human spirit may be intimately bound up with outward physical growth and ego development, this being perhaps most clearly expressed in productivity or doing-in-the-world. In later years physical decline may limit productivity, but the activity of the spirit continues through shifting the focus of personal identity from doing-in-the-world to being-in-the-world-a shift from what one does to who one is. As physical activity diminishes, the spirit begins to move toward an emphasis upon the nonphysical aspects of life. We all know individuals who, in the face of seemingly overwhelming physical disintegration, still face life with a vitality which is clearly not based in their physical well-being. This vitality is evidence of their spirit at work. It is plainly recognizable in the later years of life.

The functioning of human spirit at once provides a link between various developmental stages in life and provides the orientation in later life from which to integrate life's experiences into a meaningful whole. To the emerging ego engaged in the initial conflicts of growth and development, the dynamic of the spirit may feel somewhat foreign or "other" and may be attributed to the actions of God. In early phases of life we may only experience the dynamic of spirit directly in our quieter moments of introspection or self-reflection. It is natural for people in a religious environment to describe the dynamic of the spirit in terms of religious sentiment.

Indeed, Allport's description of mature religious sentiment very much fits with the Jungian description of the dynamics of the spirit. Allport stated that mature religious sentiment is 1 ) well differentiated; 2) dynamic in character; 3) productive of consistent morality; 4) 
comprehensive; 5) integral; and 6) fundamentally heuristic (Allport, 1950).

The spiritual dynamic may not be expressed exclusively in traditional religious language. It may also be expressed through art, philosophy, music, drama, literature, and similar creative products of the psyche. But when it is expressed in religious terminology, we may recognize it as fitting some or all of Allport's characteristics of mature religious sentiment.

Bianchi has beautifully described the dynamic of spirit in its religious expression for 22 men and women, all of whom have been leaders in their religious communities and have found positive expression through creative elderhood (Bianchi, Aging, 1982). It is clear from his careful presentation that Allport's characteristics of mature religious sentiment are present in each of these cases. It also seems clear that Stettner's comment regarding spiritual well-being in aging also holds true. Stettner suggested that spiritual well-being looks like one thing if we are observing what James called "healthy-minded" types of people but that it may look like something quite different if we are observing people who fit James's other category, that of the "sick soul" (Stettner, "Case Study", 1980). This latter category contains persons who are more susceptible to the vicissitudes of life; who seem less able to find the psychic resources to maintain creative elderhood of the sort Bianchi describes.

In the cases which follow, I attempt to respond to Stettner's call for attention to the spiritual dynamic of those who fit James's second category. These cases are drawn from the individuals with whom I minister at a county nursing home. Each of the three cases will focus upon one major challenge faced in the later years of life: 1 ) self-worth (being as opposed to doing), 2) the meaning of one's life (life review), and 3) losses in aging (integrity), each of which has been described by Whitehead ("Images," 1981).

The first case is a Polish-born, Roman Catholic woman in her early nineties. Most of her productive life she cared for her family, drawing much of her identity from her role as wife and mother. The church and personal religious devotion were present in her family of origin. As she grew older, and particularly when she entered the nursing home, she experienced the loss of her role as the family care-taker. She developed close ties with a contemplative order of religious women who included her in their community of prayer. During times of personal or family stress or unrest in Poland, she would spend much of her time before her personal altar in prayer. She saw herself as a vital spiritual link with her family here and abroad and with God.

It is clear from looking at this woman that her self-worth in her later 
years was no longer drawn from her role as family care-taker in a physical sense; rather, it was drawn from her role as the spiritual elder of the family. Her role changed from doing things for her family to being their spiritual contact. Even staff-members of the nursing home would stop by her room to ask her to pray for a particular matter. Through her inability to offer physical care for her family she was drawn to form a closer tie with the church. These ties allowed her to continue to participate in the life of her family even from her nursing home bed. Her spirit found a way to remain active throughout her bodily decline.

The second case is an American-born, Methodist woman in her early eighties. She has never married and has no close relatives. Most of her life has centered around the Methodist Church, both the local church and the larger denomination. During her late mid-life she began taking positions of leadership in her church and was certified as a laypreacher, in her sixties. She continues to orient her life around the church through her correspondence and through her daily devotions. In telling the story of her life, she speaks almost exclusively of herself in relationship to the church throughout the various phases of her life. During periods of stress she finds ways to apply the teachings of her church to her situation.

The absence of family ties has been a source of sadness for this woman in her later years, yet it seems clear that long ago she began to fill the void of personal family in her life with the family of God, her church. In looking at her life in relationship to God through her church, she is able to give meaning and value to her life past and present. The biblical admonition to store up one's treasures in heaven comes to mind in her case; she has developed a way to value her life which has little to do with physical well-being.

The last case is an American-born, Protestant woman in her early sixties. She was married, with step-children, and held a position as an efficiency expert in Boston when, in her early fifties, she suffered a crippling stroke which left her unable to walk, deaf, and speech impaired. Her husband divorced her. In the face of these stunning losses she drew upon her early religious training and her strong personal will. She stated to me that she decided that she was more than body, she is spirit. She continues to strive toward maximizing her independence. She remains faithful in her observance of religious services and personal devotions.

It seems clear to me that this woman has identified with the transcendent nature of the spirit as a means for her to transcend her physical impairments. Her faith has helped her to remain vital and determined to surmount her obstacles. Her sense of the nonphysical aspects 
of life has given her integrity in her struggle with physical and social losses and it has given her a will to live each day to her fullest capacity.

In each of these cases the creative, meaning-giving, valuational, and transpersonal character of the spirit is clear. Each of these women was able to follow the dynamic leading of the spirit at work in their souls so that psychic energy became available to counterbalance feelings of despair and hopelessness, thus allowing them to live vital lives. It is important to note that in each case the person's religious habits were not newly formed in later years but became more significant to them in later years as they faced major changes in important areas of their lives.

It is also important to note that each person drew upon her religious resources in her own fashion, choosing particular aspects of her religious heritage to make her own in daily life. This observation seems to support Brown's contention that one needs to explore "an older person's practice of devotional observance and identity as a religious person" in order to follow the path his or her spirit takes toward religious expression (Brown, "Needs," 1980, p. 78). Note also that these women did not use their religion to hide from their difficulties in life, but as a means of coping with the crises of life. Both of these observations are consistent with the conclusions of Bianchi (Aging, 1982).

An individual's spirituality is an expression of his or her spirit. It may take traditional religious expressions or it may not. Religious professionals need to be cognizant not only of the developmental issues during the latter years of life, but also of the spiritual dynamic which is striving to balance the crises of this stage of life. In so doing we may find ourselves in a better position to maximize the benefits of older persons' religious activities and experiences (Brown, p. 78). Christiansen, Curtin, Buhler, and Massarik have each noted the limits of a developmental view of aging. And each have called for a greater appreciation of the wholeness of life. Such an appreciation requires our awareness of the dynamics of the spirit and our willingness to look for the spirituality which it brings. It would be a shame to miss the beauty of the spiritual forest by concentrating on the development of the trees.

\section{References}

Allport, Gordon, The Individual and His Religion (New York: Macmillan Publishing Co., 1950).

American Heritage Dictionary (New York: Dell Publishing Co., 1973).

Bianchi, Eugene, Aging as a Spiritual Journey (New York: Crossroads, 1982).

Brown, Philip, "Religious Needs of Older Persons." In Spiritual Well-Being of the Elderly, Thornson \& Cook, eds. (Springfield: Charles C. Thomas Publisher, 1980). 
Browning, Don, Generative Man (Philadelphia: Westminster Press, 1973).

Christiansen, Drew, "Dignity in Aging: Notes on Geriatric Ethics." In Aging and the Human Spirit, LeFevre \& LeFevre, eds. (Chicago: Exploration Press, 1981).

Curtin, S., Nobody Ever Died of Old Age (Boston: Atlantic, 1972).

Hall, E., "A Pastoral Dialogue Between Psychology and Theology: Analytical Psychology and Process Theology-Human Spirit," unpublished doctoral thesis, Andover Newton Theological School, 1981).

Hiltner, Seward, Toward a Theology of Aging (New York: Human Sciences Press, 1975). Jacobi, Jolande, The Psychology of C.G. Jung (New York: Pantheon Books, 1957).

James, William, Varieties of Religious Experience (New York: Longmans, Green, \& Co., 1929).

Jung, C.G., The Collected Works of C.G. Jung (New York: Pantheon Books, 1957).

Stettner, John, "A Case Study of Spiritual Well-Being." In Spiritual Well-Being of the Elderly, Thornson \& Cook, eds. (Springfield: Charles C. Thomas Publisher, 1980).

Whitehead, Evelyn, "Religious Images of Aging: An Examination of Themes in Contemporary Christian Thought." In Aging and the Human Spirit, LeFevre \& LeFevre, eds. (Chicago: Exploration Press, 1981). 